\title{
9. JEAN CHARCOT SEABEAM SURVEY ALONG ODP LEG 112 NORTHERN TRANSECT ${ }^{1}$
}

\author{
Jacques Bourgois, ${ }^{2}$ Roland von Huene, ${ }^{3}$ Guy Pautot, ${ }^{4}$ and Philippe Huchon ${ }^{5}$
}

\section{INTRODUCTION}

A marine geophysical survey that used Seabeam, multi- and single-channel seismic reflection, gravity, and magnetic profiling was conducted in two locations along the landward slope of the Peru Trench. This survey was conducted during the SeaPERC cruise of the Jean Charcot in July 1986 (Bourgois et al., 1986a; Bourgois et al., 1986b; Bourgois et al., 1987; Bourgois et al., in press). These areas were two possible drilling locations for ODP Leg 112, which was scheduled to begin in November 1986. The drilling transects center around latitudes of $5^{\circ} 30^{\prime} \mathrm{S}$ and $9^{\circ} 30^{\prime} \mathrm{S}$, along multichannel seismic lines CDP-3 and CDP-2, respectively. The northern transect is located in the Paita Zone (Fig. 1, Box 2), and the southern transect is in the Chimbote Zone (Fig. 1, Box 6).

During Leg 112, we drilled two sites (683 and 685) in the Chimbote area. This became the northern transect of Leg 112. Here, we report the Seabeam data acquired during the SeaPERC cruise. Drilling results from Sites 683 and 685 , the CDP-2 multichannel seismic record, and the Seabeam data provide a threedimensional view of this region.

\section{BACKGROUND AND SCIENTIFIC OBJECTIVES}

The area surveyed near Chimbote, between a latitude of $9^{\circ} \mathrm{S}$ and $10^{\circ} \mathrm{S}$ and a longitude of $80^{\circ} \mathrm{W}$ and $81^{\circ} \mathrm{W}$ (Figs. 1 and 2 , back-pocket foldout), includes the axis of the Peru Trench as well as parts of the seaward and landward slopes. A peculiar elongated ridge on the seaward slope constricts the flat axial floor of the trench. The landward slope includes a steeper, rough lower portion; a gentle, smooth middle part; and a smooth, upper part above a 400-m scarp. This area was a focal point of the Nazca Plate Project and contains one of the three Common-Depth-Point (CDP) seismic-reflection records (i.e., CDP-2) that highlighted the geophysical data reported from the project (Kulm et al., 1981).

Jones (1981) also singled out the area off Chimbote for study using seismic-reflection records. Jones concluded from his study of refraction and gravity data that the entire landward slope of the trench is composed of material accreted from the Nazca Plate, despite his observations of a higher velocity and density than normal for such rocks. Kulm et al. (1981) concluded from studying the CDP-2 and regional data that the metamorphic basement of the continental crust could extend between 26 and $115 \mathrm{~km}$ landward of the trench axis (Fig. 3). They also proposed that the peculiar ridge on the seaward side of the trench was a block uplifted by thrust faulting and cited it as an example of the initial stage in a process by which ocean crust and sediment are mixed in an accretionary complex.

\footnotetext{
${ }^{1}$ Suess, E., von Huene, R., et al., 1988. Proc. ODP, Init. Repts., 112: College Station, TX. (Ocean Drilling Program).

2 Département de Géotectonique, (CNRS-INSU), Université Pierre et Marie Curie, 4 Place Jussieu, 75252 Paris Cedex, France.

3 U.S. Geol. Survey, 345 Middlefield Road, Menlo Park, CA 94025.

4 IFREMER Centre de Brest, BP 337, 29273 Brest Cedex, France.

5 Département de Géologie, Ecole Normale Supérieure, UA 215 (CNRSINSU), 24 Rue Lhomond, 75252 Paris Cedex, France.
}

The geophysical data in this area was summarized in the Ocean Margin Drilling Project, Atlas 9 (Hussong et al., 1985), which included unpublished CDP seismic-reflection data from Petro-Peru (Thornburg, 1985). Those data detailed the structure of the forearc basins on the shelf and tied two exploratory drill holes to CDP-2 data. Those holes (Fig. 3) were drilled into the metamorphic basement, which was covered unconformably by a sequence of Eocene and younger shelf sediment. Record CDP-2 was reprocessed, greatly clarifying the geometry of the reflective sequences and imaging greater structural details (von Huene et al., 1985). Accretion of sediment from the Nazca Plate was shown to lie beneath the lower slope. The upper slope was composed of the continental section that could be followed from the forearc basin area; this slope was sampled in the drill holes. The continental section was also recovered by dredging during a cruise of the Moana Wave in February 1985 (Kulm et al., this volume; T. Thornburg, pers. comm., 1986). This crust of continental affinity was normally faulted and ended somewhere in a $15-\mathrm{km}$ span of the middle-slope area, and about $15 \mathrm{~km}$ landward of the trench axis (Fig. 4).

During preparation for drilling Leg 112, a site survey was conducted in 1985 from the Moana Wave. That survey included swath-mapping with the SeaMARC instrument system and CDP seismic-reflection survey (see Hussong et al., this volume). Our survey of the Chimbote area was planned with data from the Moana Wave survey provided by D. Hussong.

The objectives of our survey in the Chimbote area were as follows:

1. To provide detailed bathymetry for studying tectonics in three dimensions, which might help to define the termination of crust with continental affinity and the tectonic regime at this location.

2. To complete the suite of seismic data required to fully assess drilling safety at ODP drilling sites in this area.

The U. S. Geological Survey multichannel instrument system was deployed for that part of the survey that obtained records crossing CDP-2 at each proposed site. Just before beginning our survey, the Jean Charcot was severely shaken by an earthquake at about $1930 \mathrm{~L}, 17$ July. The severity of the shaking indicated an earthquake of large magnitude nearby. Two days later, we learned from the Peruvian Geophysical Institute that an earthquake of 7.8 on the Mercalli scale was located near the southwest corner of the Chimbote survey area $\left(80^{\circ} 51^{\prime} 26^{\prime \prime} \mathrm{W}, 9^{\circ} 31^{\prime} 65^{\prime \prime} \mathrm{S}\right.$; initial time of 0038.5 UTC). This location placed the causative fault in the oceanic crust, not in the subduction zone.

\section{ANALYSIS OF DATA}

The Seabeam map (Figs. 5 and 2), the mesh-net perspective diagrams (Fig. 6), and the seismic records of the Chimbote area exhibit five morphological domains of tectonic significance. From east to west, these are referred to as the upper slope, the middle slope, the lower slope, the trench, and the seaward slope.

The upper slope is represented by only a small area at the northeastern corner of our surveyed area (Figs. 5 and 2). However, the steep flexure and faulting of the boundary between the 


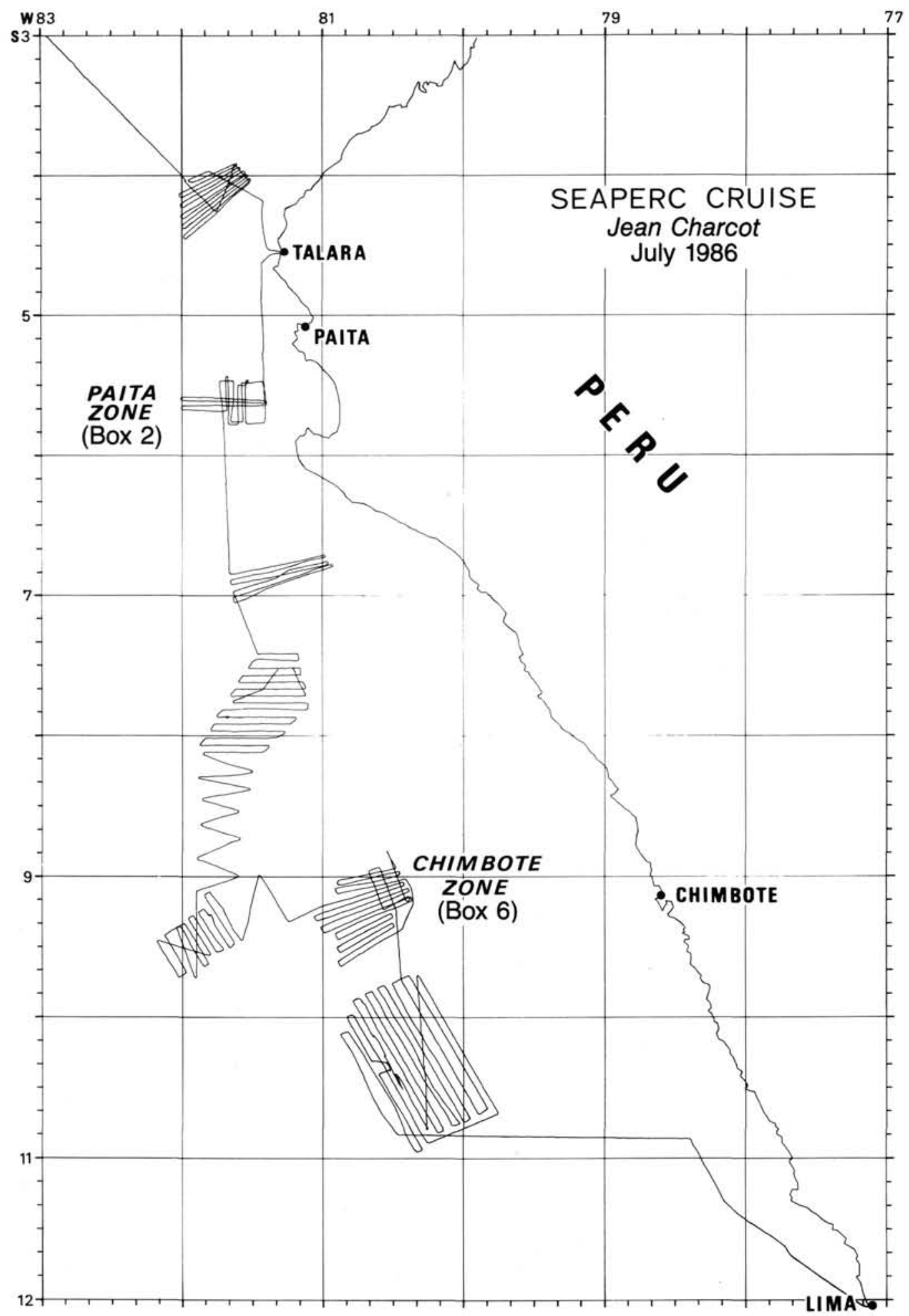

Figure 1. Track line of the Jean Charcot during the SeaPERC cruise (July 1986). The area discussed here is Box 6 off Chimbote.

upper and middle slopes is exposed as a straight scarp paralleling the strike of the slope. Near seismic line CDP-2, this steep scarp is about $1000 \mathrm{~m}$ high. The adjacent downslope lobate mass below it protrudes onto the middle-slope terrace. Reflectors along the scarp that form the landward boundary of the middle-slope terrace are weak and obscured by diffractions. Our interpretations were thus guided mainly by Seabeam morphology.

The middle slope is characterized by a terrace almost as flat as the floor of the trench. Shallow, closed depressions are located landward, and a series of highs occurs seaward. On a large scale, these features are elongated parallel to the regional trend; 

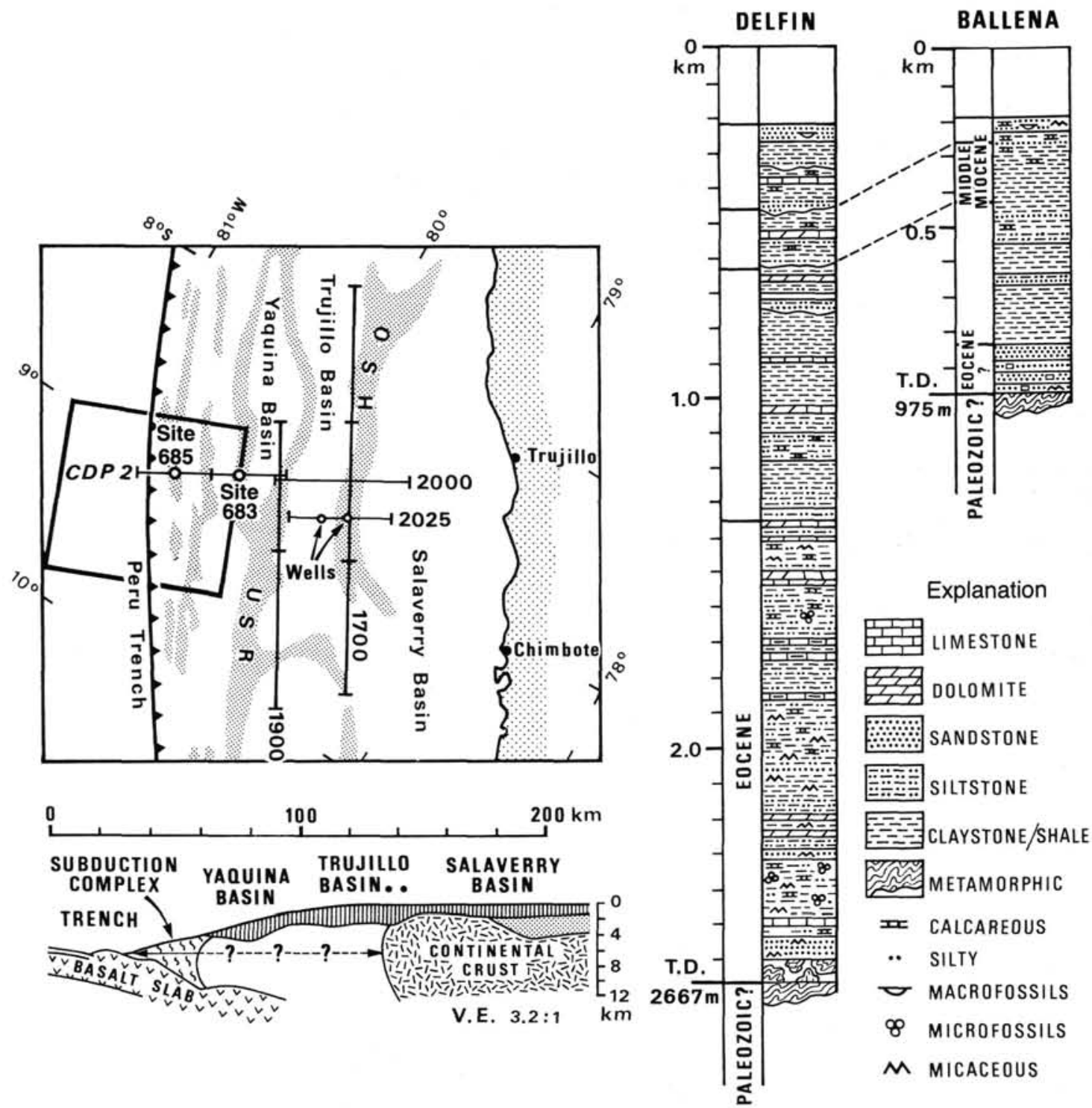

Figure 3. Map showing the location of the Seabeam survey in the Chimbote area, the CDP-2 multichannel seismic line, two other published multichannel records $(2000,2025)$, and drill holes to metamorphic basement (Kulm et al., 1985). Bottom left of figure: Diagrammatic cross section of the Peruvian margin (Kulm et al., 1985) along the CDP-2 multichannel seismic line (Peru-2). Industry wells Delfin and Ballena are depicted to the right. Their location is indicated on the map and is denoted by circles.

in greater detail, however, the contours appear to meander somewhat aimlessly. Uplift of the seaward highs probably caused the closure of the adjacent lows. The middle-slope terrace recorded a landward tilt of the middle slope, which was also recorded by the landward tilt of sub-bottom reflectors beneath the middle slope. Locally, these lows show flat reflections from ponded sediment. Active tectonism is evident from landward tilting of these flat reflectors just south of CDP-2.

The lower-slope morphology is the most irregular of the landward slopes of the trench. Single-channel seismic records indicate slump debris in a central part (Bourgois et al., 1987). In general, morphological features parallel the trench; no strong transverse trend was observed. Small basins or terraces alternate with sections of steepened slope. The base of the slope is consistently steep and marks the deformation front of the subduction zone. Just behind the deformation front is an area of gentle slope consistent with the morphology of a tilted thrust slice that underlies the base of the lower slope.
The trench axis is marked by a flat floor consistent with the ponding of sediments there. The trench floor becomes constricted where a large ridge enters the subduction zone (Kulm et al., 1981). Opposite the ridge, one can see a gentle protrusion of the lower landward slope as though the approaching ridge had already begun to affect not only the trench floor but the deformation front as well.

The Seabeam map (Fig. 2, back pocket) at 20-m contour intervals and the mesh-net diagram (Fig. 6) show the many small normal faults accompanying the downward flexure of the seaward slope as the oceanic crust of the Nazca Plate bends before entering the trench. These faults are spaced at intervals of about $2.5 \mathrm{~km}$ and have an average height of about $100 \mathrm{~m}$.

A large ridge reaching 700 to $800 \mathrm{~m}$ above the oceanic crust is superimposed on this morphology. The ridge is about $40 \mathrm{~km}$ long and exhibits an asymetric profile having a gentle ramp that dips toward the trench and a steep seaward slope facing the ocean basin. In its middle part, the ridge is laterally offset about $8 \mathrm{~km}$ 


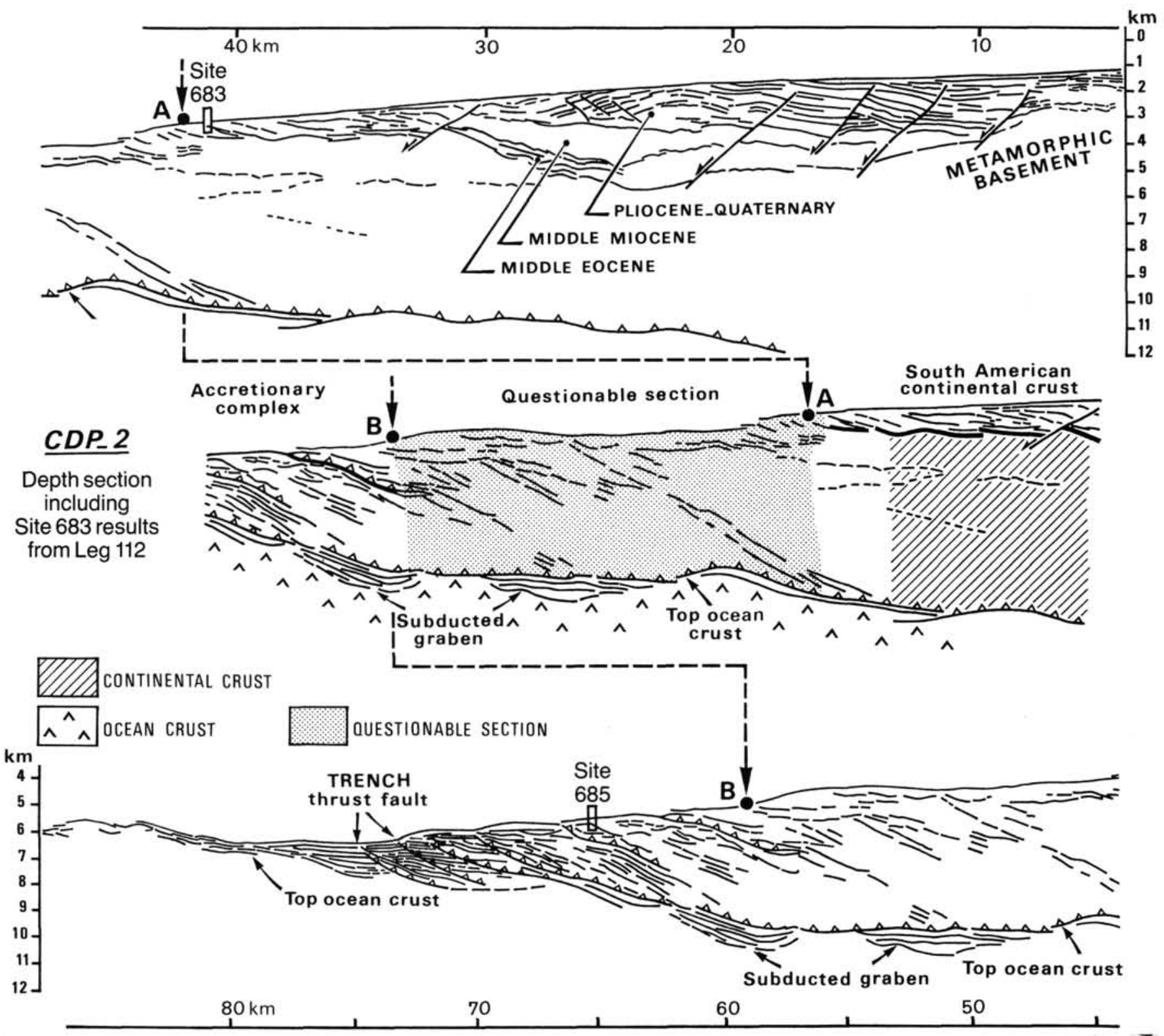

Figure 4. Depth section of CDP-2 multichannel seismic line (von Huene et al., 1985) and location of the questionable section in the middle-slope area.

to the left. The strike of the northern and southern sections of the ridge diverge about $10^{\circ}$ across this offset. The fault along the offset intersects the trench at about $75^{\circ}$. Closed depressions occur seaward of each segment of the ridge. A 200 -m-high saddle separates the trench from the closed depression located along the seaward side of the southern segment of the ridge.

Because of its transverse orientation, the fault between the two segments of the ridge appears spectacular in the Seabeam bathymetry, but it is not well displayed in the single-channel seismic records. This cross fault can be seen only in seismic line CDP-2 (Kulm et al., 1981; von Huene et al., 1985). In that record, the cross fault has displaced the trench fill. We did not observe such a displacement at the seaward end of the morphology associated with the fault, and thus the fault produces only local deformation. The transverse fault cannot be followed seaward into the structure of the Nazca Plate. These relationships suggest that the flexure of the oceanic crust is younger than the offset of the ridge. Consequently, we inferred that the transverse fault had an inherited origin and that reactivation occurred where the Nazca Plate bent during descent beneath the Andean margin.

The ridge is shaped like a tilted block and has a steep, faulted slope that faces the sea and a gentle tilted slope that faces land. Single-channel seismic records (Fig. 7) show a pelagic sediment cover on the gentle landward slope of the ridge. The pelagic seismic facies continues eastward beneath the ponded axial fill of the trench to the deformation front. The turbidite fill of the trench is horizontal and undeformed as far as the subduction front. Thus, the ridge was tilted before deposition of the trench fill.

In previous studies (Kulm et al., 1981), scientists focused on the origin of the ridge. They made a case for tilting of the ridge during the past 3000 years. The Seabeam bathymetry and accompanying geophysical observations provide more details for reevaluating the origin of the ridge. We believe that the ridge is a tectonic feature of the Nazca Plate that was reactivated during plate flexure. Obviously, this ridge has not tilted since sediment filled the trench axis (Fig. 7; see also Moore and Taylor, this vol- 


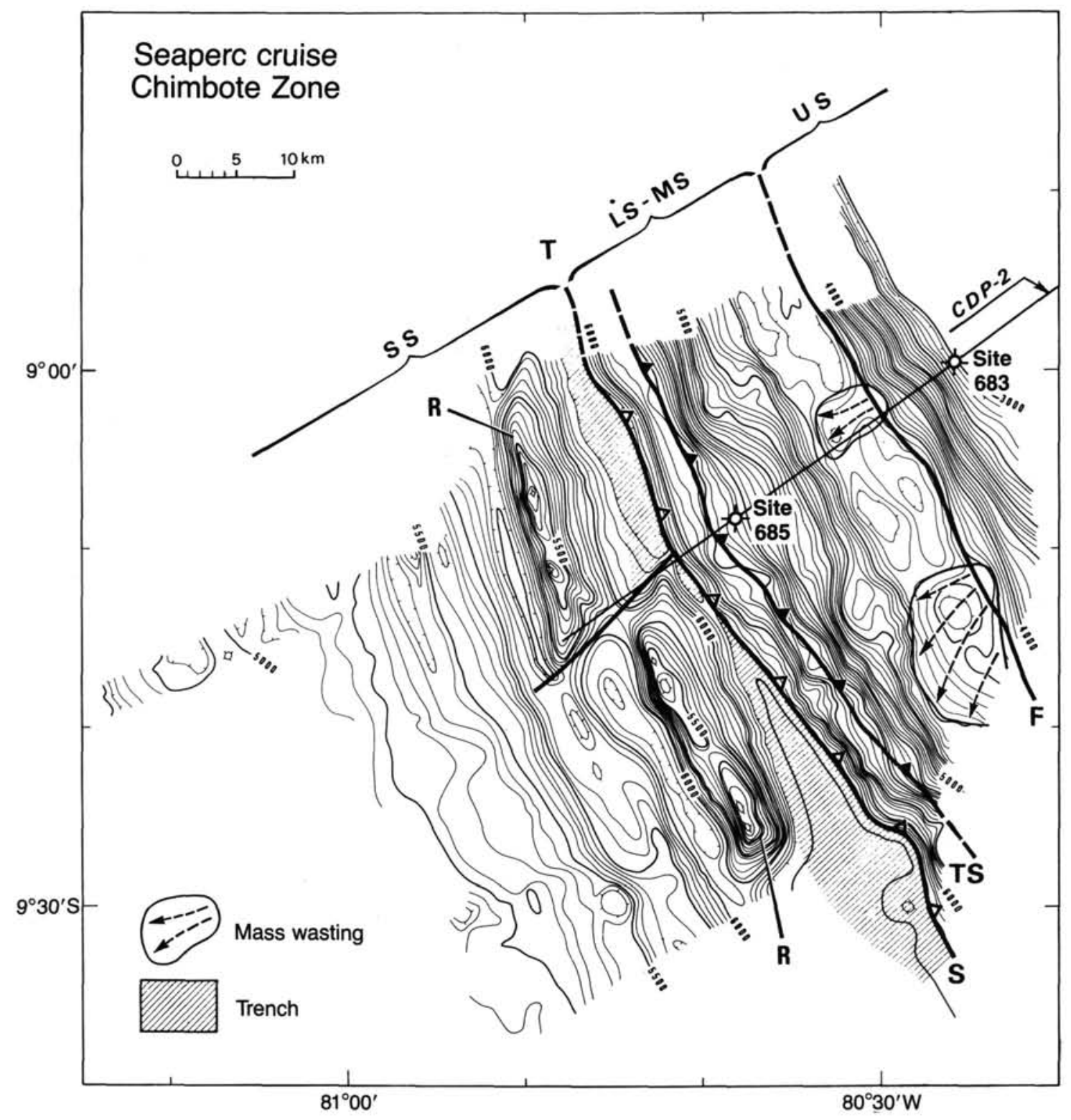

Figure 5. Seabeam bathymetric map of the Chimbote area (contour interval at $50 \mathrm{~m}$ ). US = upper slope; $M S=$ middle slope; $L S=$ lower slope; $T=$ trench; $S S=$ seaward slope; $F=$ normal fault at the upper-slope/middle-slope boundary; $S$ $=$ subduction contact; $T S=$ thrust slice; $R=$ ridge. Sites 683 and 685 (drilled on Leg 112) are also shown.

ume). The 5-km-wide trench fill developed during $\sim 0.5 \mathrm{Ma}$ at a convergence rate of $10 \mathrm{~mm} / \mathrm{yr}$.

\section{CONCLUSIONS}

Adding Seabeam bathymetry and single-channel seismic data from the SeaPERC cruise of the Jean Charcot along the CDP-2 seismic line provided a three-dimensional view of the structure at the contact between the South American continent and the accretionary complex associated with the Peruvian subduction zone. On the basis of this Seabeam and seismic data from the Chimbote area, our observations are summarized as follows:

1. The continental slope of Peru consists of three distinct morphological and structural domains, instead of two, as reported from conventional bathymetric data. The upper, middle, and lower slopes occur from east to west.
2. We assumed that the scarp of the upper-middle slope boundary is a normal fault because of (1) the landward tilt of the middle-slope terrace and the consequent trapping of sediment, (2) the collapse of the upper-slope planar surface; we inferred that the middle-slope terrace is a normal, faulted remnant of the upper slope, (3) the similarity of the topography near Chimbote with the Paita Zone, where massive collapse is more evident (Bourgois et al., 1986a; Bourgois et al., 1987), (4) the reevaluation of the CDP-3 seismic record (von Huene et al., unpublished data) in the three-dimensional framework provided by Seabeam bathymetric data and broad geophysical coverage.

3. A 3- to 4-km-thick thrust slice is well defined at the base of the lower slope, above the subduction zone. Accretion occurs in the Chimbote area.

4. The lower-middle slope boundary is not as well defined as in the Paita area (Bourgois et al., 1987). The tensional-compres- 


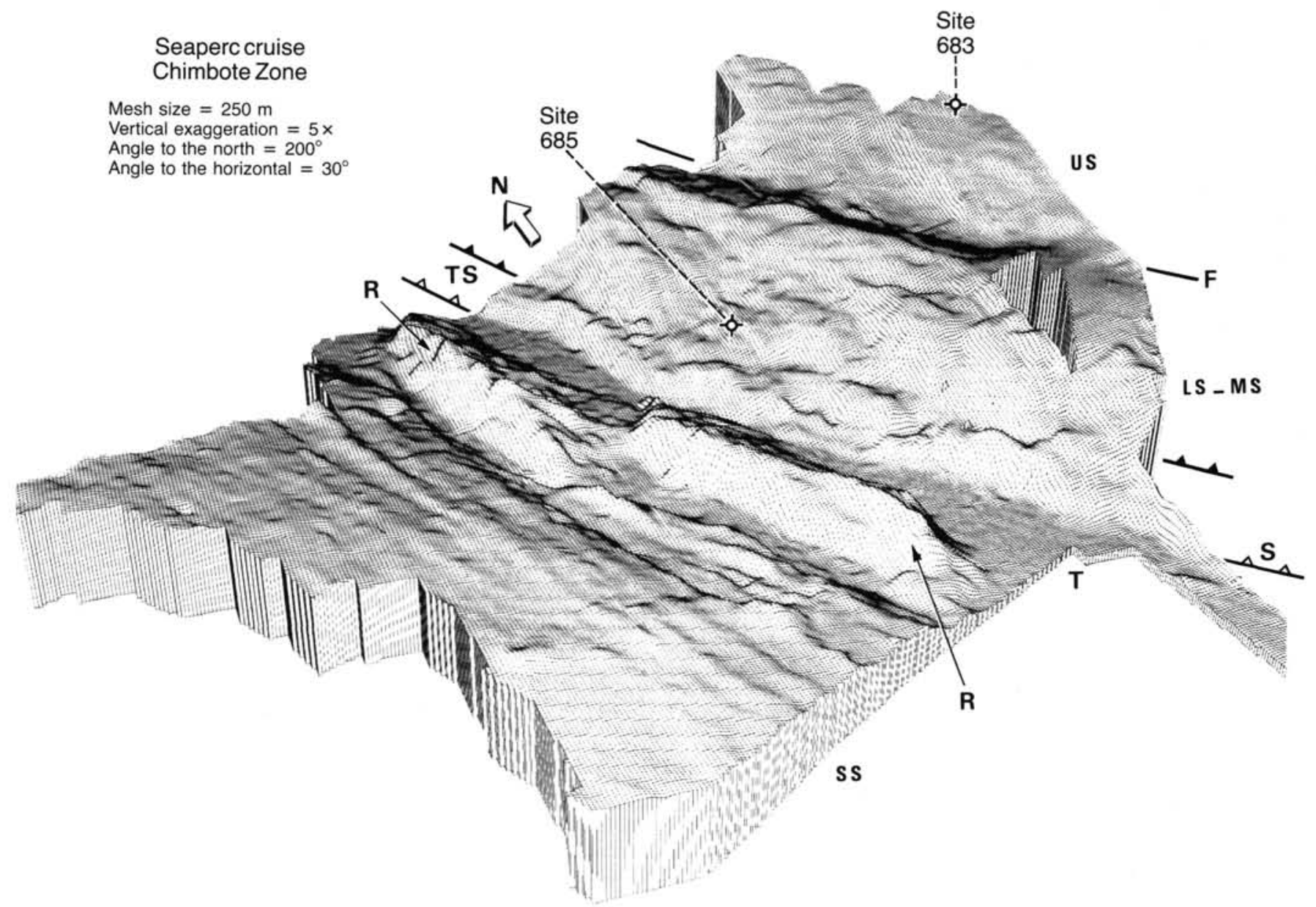

Figure 6. Mesh-net perspective diagram of bathymetry in Figure 4 for Sites 683 and 685. See Figure 4 for explanation of terms.

sional tectonic boundary is not well defined but occurs between the middle-slope terrace and the lower-slope thrust slice.

5. The ridge seaward of the trench is an inherited feature of the Nazca Plate that reactivated as the plate flexed before entering the trench. The tilted blocks that form the ridge have not rotated since deposition of the trench fill.

The Peruvian margin exhibits a young accretionary complex that is stacked against the front of truncated continental crust. This structure is similar to that studied during DSDP Leg 84 off Guatemala across the landward slope of the Middle America Trench (Aubouin et al., 1982), where little accretion was found (Moore et al., 1986). Some studies indicate that the Peruvian margin is a "Convergent Extensional Margin" (Aubouin et al., 1984). As suggested by the mechanism of extension, we believe one might use the term "Collapsing Convergent Margin" instead. The Andean continental margin model emphasizes a high decoupling along the subduction contact, strong tectonic erosion, and related massive subsidence and collapse as seen previously off Japan (Langseth et al., 1981; von Huene et al., 1982; Karig et al., 1983) and off Puerto Rico (Le Pichon et al., 1985).

\section{ACKNOWLEDGMENTS}

The SeaPERC cruise was supported by IFREMER and CNRS-INSU as well as USSAC. We thank the captain and crew of the Jean Charcot and Teniente Guillermo Hasembank, representative of the Peruvian Navy. We appreciate the help of the French Embassy in Lima.

\section{REFERENCES}

Aubouin, J., von Huene, R., Baltuck, M., Arnott, R., Bourgois, J., Filewicz, M., Kvenvolden, K., Leinert, B., McDonald, T., McDougall, K., Ogawa, Y., Taylor, E., and Winsborough, B., 1982. Leg 84 of the Deep Sea Drilling Project: subduction without accretion, Middle America Trench off Guatemala. Nature, 297:458-460.

Aubouin, J., Bourgois, J., and, Azema, J., 1984. A new type of active margin: the convergent-extensional margin, as exemplified by the Middle America Trench off Guatemala. Earth Planet. Sci. Lett., 67: 211-218.

Bourgois, J., Pautot, G., Bandy, W., Boinet, T., Chotin, P., Huchon, P., Mercier de Lepinay, B., Monge, F., Monlau, J., Pelletier, B., Sosson, M., and von Huene, R., 1986a. Tectonic regime of the Andean convergent margin off Peru (SeaPERC cruise of the R/V Jean Charcot, July 1986). C. R. Acad. Sci. Paris, 303:1599-1604. 1986b. Structure of the Peru inner trench wall: $4^{\circ}-11^{\circ} \mathrm{S}$. Eos, Trans. Am. Geophys. Union, 67(44):1196.

1987. The tectonic regime of the Andean continental margin off Peru. Eos, Trans. Am. Geophys. Union, 68(44):1498. , in press. Seabeam and seismic reflection imaging of the Andean continental margin. Earth Planet. Sci. Lett.

Kulm, L. D., Prince, R. A., French, W., Johnson, S., Masias, A., 1981. Crustal structure and tectonics of the central Peru continental margin and trench. Geol. Soc. Am. Mem., 154:445-468.

Jones III, P. R., 1981. Crustal structures of the Peru continental margin and adjacent Nazca Plate, $9^{\circ}$ S latitude. Geol. Soc. Am. Mem., 154: 393-422.

Hussong, D. M., Dang, S. P., Kulm, L. D., Couch, R. W., and Hilde, T.W.C., 1985. Ocean Margin Drilling Program, Regional Atlas Series, Atlas 9: Woods Hole, MA (Marine Science International). 
Karig, D. E., Kagami, H., Akiba, F., Bray, C. J., Cadet, J. P., Charvet, J., Coulbourn, W., Fujioka, K., Kinoshita, H., Lagoe, M., Lang, T. H., Leggett, J. K., Lombari, G. A., Lundberg, N., Machihara, T. Matsumoto, R., Mukhopadhyay, P., Niitsuma, N., Smith, A. J., Stein, C. L., and Taira, A., 1983. Varied responses to subduction in Nankai Trough and Japan Trench forearcs. Nature, 298:148-151.

Langseth, M. G., von Huene, R., Nasu, N., and Okada, H., 1981. Subsidence of the Japan Trench forearc region of northern Honshu. In Blanchet, R., and Montadert, L. (Eds.), Géologie des marges continentales: Paris (26th Int. Geol. Congress, Oceanol. Acta, Spec. Publ.), 173-179.

Le Pichon, X., Iiyama, J., Bourgois, J., Mercier de Lepinay, B., Tournon, J., Müller, C., Butterlin, J., Glaçon, G., 1985. First results of the test dives of the French submersible Nautile in the Puerto Rico Trench (Greater Antilles). C. R. Acad. Sci. Paris, 10:743-749.
Moore, G .F., Shipley, T. H., and Lonsdale, P., 1986. Subduction erosion versus sediment offscrapping at the toe of the Middle America Trench off Guatemala. Tectonics, 5:513-523.

Thornburg, T., 1985. Multichannel seismic interpretations-shelf and upper slope basins. In Hussong, D. M., Dang, S. P., Kullm, L. D., Couch, R. W., and Hilde, T.W.C. (Eds.), Ocean Margin Drilling Program, Regional Atlas Series, Atlas 9: Woods Hole, MA (Marine Science International), 8.

von Huene, R., Langseth, M., Nasu, N, and Okada, H., 1982. Summary of Cenozoic tectonic history along the IPOD Japan Trench transect. Geol. Soc. Am. Bull., 93:829-846.

von Huene, R., Kulm, L. D., and Miller, J., 1985. Structure of the frontal part of the Andean convergent margin. J. Geophys. Res., 90(B7): 5429-5442.

Ms 112A-109

A

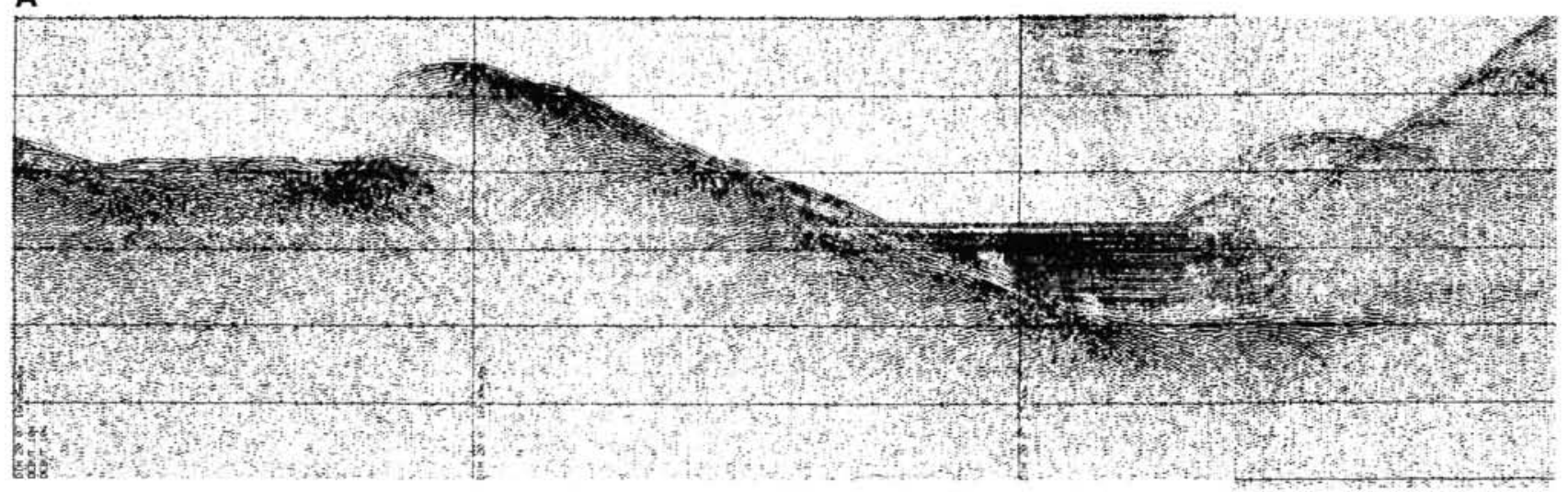

B

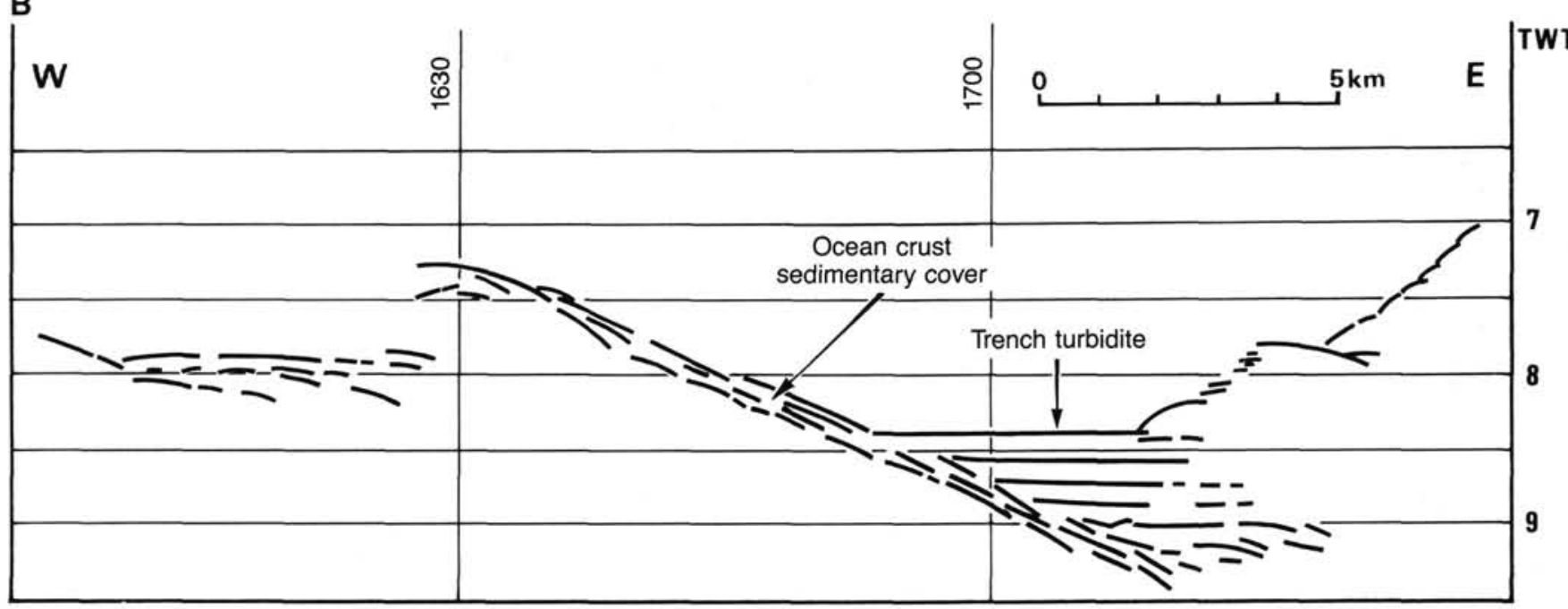

Figure 7. A) Single-channel seismic profile 90, recorded during the SeaPERC cruise. B) Interpretation of the profile shows that the basalt and sedimentary covers of the ridge (Nazca Plate) dip eastward beneath the undeformed, ponded axial fill of the Peru Trench. See text for explanation. 